\title{
Increasing risk of glacial lake outburst floods as a consequence of climate change in the Himalayan region
}

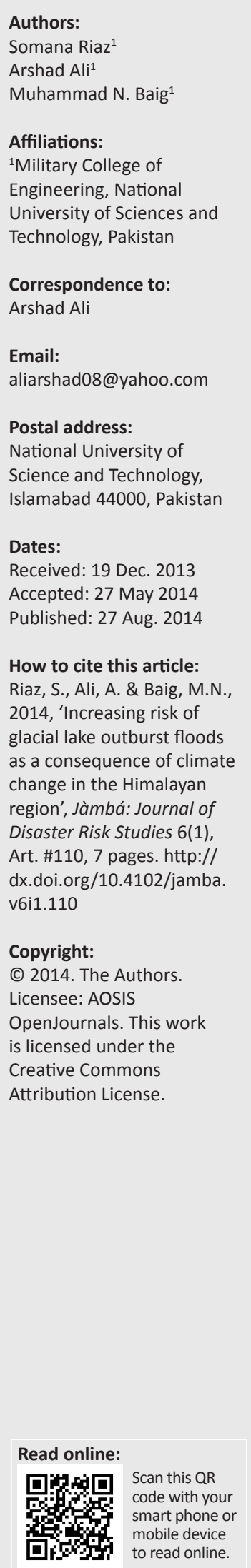

The greater Himalayan Mountains host the largest snow covered area outside the polar regions and serves as the source for some of the major fluvial systems of the world. The region acts as the lifeline for approximately $10 \%$ of the world's population. The terrain is geologically active, highly susceptible to climate change processes and plays a significant role in global hydro-meteorological cycles and biodiversity. With the increasing impacts of climate change to the glaciers and ice caps during the past few decades, people living in the Himalayas have become vulnerable to a higher risk of floods, avalanches and glacial lake outburst floods (GLOFs). This study reviewed the work carried out by earlier researchers to understand the history and science of GLOFs and their potential risk to the communities in the Himalayan belt, particularly in Pakistan.

\section{Introduction}

\section{Himalayan glaciers: The 'Third Pole' of the world}

The Himalayan Mountain system is currently amongst the most active tectonic belts on earth. The extensive Himalayan system traverses eight countries: Afghanistan, Bangladesh, Bhutan, China, India, Myanmar, Nepal and Pakistan and helps sustain ten major river systems - the Amu Darya, the Brahmaputra, the Ganges, the Indus, the Irrawaddy, the Mekong, the Salween, the Tarim, the Yangtze and the Yellow. It is an east-west trending mountain chain with exceptionally high relief. It covers an area of about $2400 \mathrm{~km}^{2}$ within the $3500 \mathrm{~km}$ stretch of the Hindu Kush-Karakoram-Himalayan $(\mathrm{HKH})$ ranges.

The glaciers of the $\mathrm{HKH}$ are the third largest ice reserves that lie outside the polar region, with an estimated area of about $33000 \mathrm{~km}^{2}$. According to a study conducted by Bajracharya, Mool and Shrestha (2007), approximately 15000 glaciers and about 9000 glacial lakes were documented in the Himalayan region from 1999 to 2003. Indeed, Dyhrenfurth (1955) termed it the 'Third Pole' on the basis of its high concentration of glaciated water and ice cover. These glaciers are one of nature's greatest renewable depositories of fresh water. Asia's largest perennial rivers, such as the Indus, the Ganges and the Yangtze, are fed by the meltwater from the Himalayan glaciers, which are a source of fresh water to nearly a quarter of the global population settled in the downstream areas of the river basins. The mountain system itself hosts many diverse cultures and an extensive diversity of flora and fauna. It also acts as a barrier to the northerly winds during winters and restrains the monsoon system which is the major source of precipitation for South Asia (Figure 1).

As a result of rapid industrialisation and anthropogenic activities during the past few decades, there has been an increase in global temperatures and a rapid retreat of snow cover globally. Glaciers are good indicators for studying variation in the air temperature over the earth's history. These ice masses are being extensively studied to understand the recent process of global warming. Following the termination of the glacier advance at the end of the Little Ice Age (more than 100 years ago), a general trend of depletion and retreat has been observed in glaciers around the world. The Himalayan glaciers are no exception to the prevailing impacts of global warming and climate change. As a response to the warming atmospheric temperatures, glaciers melt, forming lakes at the terminus of the ice mass or within the main body of the glaciers (Figure 2). As a result of the rapid accumulation of melt water in these lakes, the end moraine may burst in what is known as a glacial lake outburst flood (GLOF), causing catastrophic flooding in the downstream riparian areas (Richardson \& Reynolds 2000).

Over the past few years, the HKH region has experienced multiple GLOF events that have resulted in considerable damage to communities, their livelihoods and infrastructure. Along with an evident increase in global temperatures, findings from recent studies (see 'Literature review' section below) have revealed the appearance of incipient lakes and marked the widening of existing ones within the region, increasing the risk of such events becoming even more 


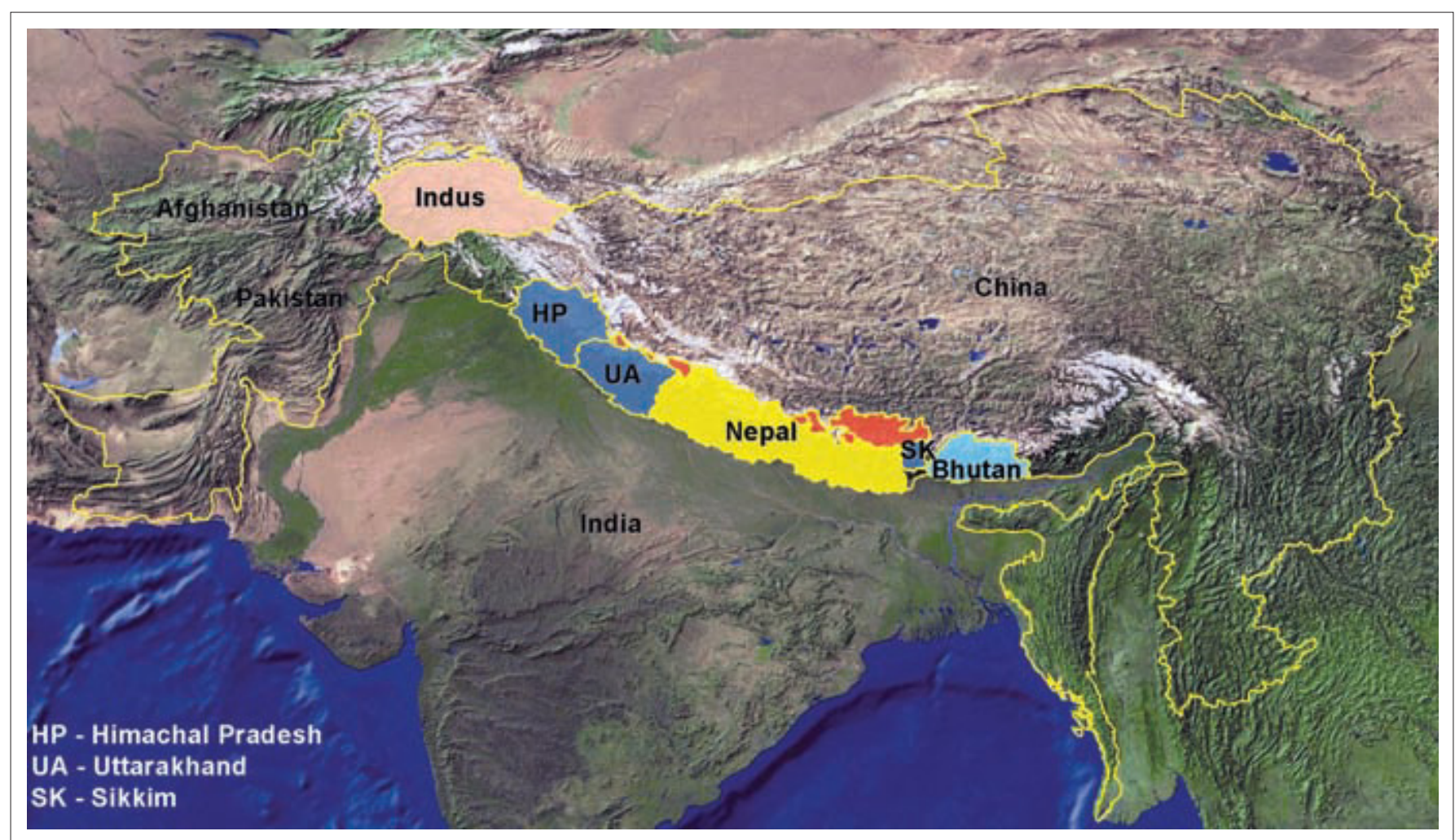

Source: Bajracharya, S.R., Mool, P.K. \& Shrestha, B.R., 2007, 'Impact of climate change on Himalayan glaciers and glacial lakes: Case studies on GLOF and associated hazards in Nepal and Bhutan', Report by the International Centre for Integrated Mountain Development in cooperation with United Nations Environment Programme Regional Office Asia and the Pacific, Kathmandu FIGURE 1: Map of the glacial bodies (in colour) along the Himalayan belt, with Indus shown as the river system originating in the Himalayas.

frequent and posing a greater risk of potential losses to the Himalayan terrain.

Pakistan heavily depends on its riverine system which has its source in the HKH glaciers and the northern part of the country has experienced a number of GLOFs caused by melting glaciers. It is therefore important to understand the changing climate and its effect on these glaciers in order to determine potential GLOF sites in the country. The present study focuses on summarising existing research on the risk of GLOFs in the Himalayas, in general, and the probability of such catastrophic events in Pakistan, in particular.

\section{Literature review}

Faced with the global trend of rising surface temperatures and its subsequent impacts on the ice masses around the globe, researchers are now keenly focused on studying the glacial environments and their response to the changing climate. One of the most threatening processes that is taking place at an accelerated rate in the glaciers is the development of glacial lakes. As the Himalayan range serves as a homeland for a quarter of the population in Asia, a large population is at risk from potential catastrophic outburst flooding. There is a greater need to study the glacial lakes and the potential risk sites in the area.

In the 1980s, different scientists worked on analysing the outburst flooding events in the Himalayan terrain. Goudie (1981) and Miller (ed. 1984) reported that a total of 339

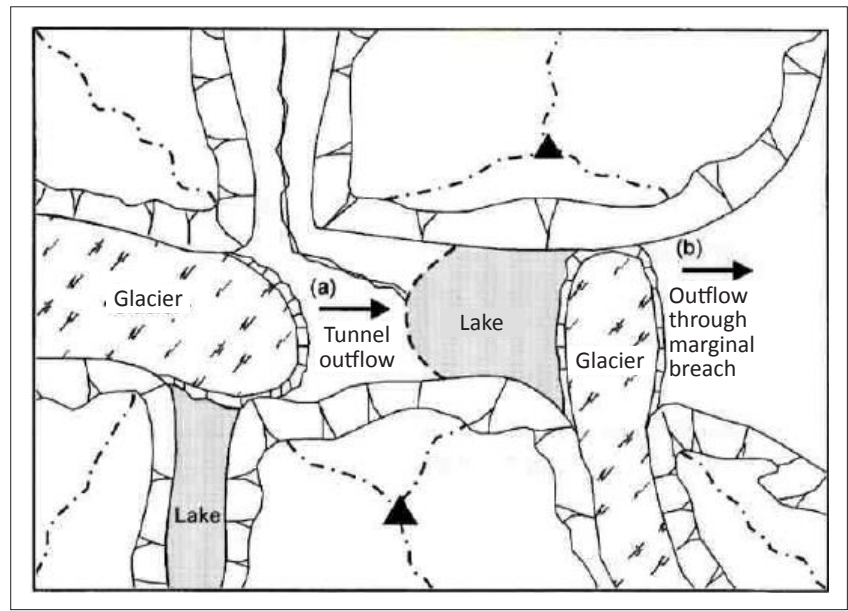

Source: Walder, J.S. \& Costa, J.E., 1996, 'Outburst floods from glacier-dammed lakes: The effect of mode of lake drainage on flood magnitude', Earth Surface Processes and Landforms $21,701-723$

FIGURE 2: Two patterns of glacial lakes and their breach mechanisms, (a) indicating the flow of meltwater through a glacial body and (b) indicating the breaching of a glacier at its margins.

disasters occurred in 1980 along the Karakorum Highway and the most destructive of these were GLOF events. A study by Hewitt (1982) identified that about 35 catastrophic GLOF events have occurred in the Karakorum Range during the past two centuries.

With the onset of the new millennium, research in the field of GLOFs has gained attention, in view of the large population that is vulnerable to the effects these hazardous events. The International Centre for Integrated Mountain Development 
(ICIMOD) and various UN organisations have been actively carrying out extensive studies on the probable hazard site of GLOFs in the Himalayas and the communities that are at a higher risk of suffering the impacts of these events. These organisations, along with the support of governments and local communities, have been organising community awareness and training activities to enhance their capacity for the future hazard events in their vicinity.

Other recent research into this field includes a study by Richardson and Reynolds (2000), producing an overview of glacial lakes in the Himalayas. Bajracharya et al. (2007) researched the impacts of climate change on Himalayan glaciers and glacial lakes through a study conducted in joint collaboration with ICIMOD and the UN. Together, they investigated the temperature variations and the increasing retreat of the Himalayan glaciers which have been causing an increase in the number of glacial lakes and outburst flooding events. Rasul, Dahe and Chaudhry (2008) carried out research on the melting glaciers in the $\mathrm{HKH}$ region of Pakistan, analysing meteorological data to determine the isotherm shift in the high elevation areas and addressing the anthropogenic influences on Siachen Glacier. The United Nations Development Programme (2010) launched a project in 2008 to monitor the situation in the Himalayan glaciers and glacial lakes, which aimed at minimising the risk of the communities in the region. Bashir and Rasul (2010) carried out meteorological data analysis for the estimation of snow cover in the Pakistani region of the Himalayas. Ives, Shrestha and Mool (2010), under the ambit of the ICIMOD, carried out a study on the GLOFs and expected damages from these lakes in Nepal to extensively identify the vulnerable areas and develop an effective coping mechanism for the communities. Ashraf et al. (2011) carried out research to identify the glacial lakes at risk for outburst floods in the Karakorum Range. Their primary focus was on the use of geographic information systems and satellite data to critically analyse the effects of climate change in the region.

\section{Global climate change trend}

Glacial environments are highly susceptible even to minute changes in the atmospheric conditions because thermal variations are more evident at high altitudes. The earth's atmospheric temperature changes over time and is generally influenced by the amount of solar radiation (terrestrial) entering our atmosphere, volcanic activity (geothermal) and rate of fossil fuel utilised (human activity). The rise and fall in the amounts of solar energy intruding on the earth (mainly in the far north during summer) is a foremost driving mechanism behind climate change (Milankovitch 1920). The Intergovernmental Panel on Climate Change (IPCC) (2001) reported an estimated increase in the concentration of atmospheric carbon dioxide from a pre-industrial value of about $280 \mathrm{ppm}$, to $379 \mathrm{ppm}$ in 2005 . Studies of the ice cores indicated that this level has far exceeded the natural range (180 ppm - 300 ppm) over the last 650000 years. Data projections for future atmospheric trends indicate that the level of atmospheric carbon dioxide is likely to double from its pre-industrial level within the next 50-100 years (Figure 3).

The rapid increase in global population and human activities has had significant adverse effects on the earth's atmosphere. According to the IPCC (2001), the average surface temperature of the earth has increased between a range of $0.3^{\circ} \mathrm{C}$ and $0.6^{\circ} \mathrm{C}$ within a short time span of about a hundred years, with the 12 warmest years ever recorded occurring in 1990s and the 2010s. This is predicted to continue during the present century (Figure 4). By 2100, the predicted increase in temperature over the Indian subcontinent is expected to be between $3.5^{\circ} \mathrm{C}$ and $5.5^{\circ} \mathrm{C}$ higher than at present, with an even higher increase anticipated for the Tibetan Plateau (Lal 2002). The increasing trend of thermal variation around the globe has resulted in an accelerated rate of formation of new glacial lakes and thus an increased risk of potential GLOFs.

The global trend of increasing temperatures is also replicated by the shifting thermal regime in different parts of Pakistan and is most evident in the northern high elevation meteorological stations located in the HKH. Rasul et al. (2008) carried out an analysis of meteorological data

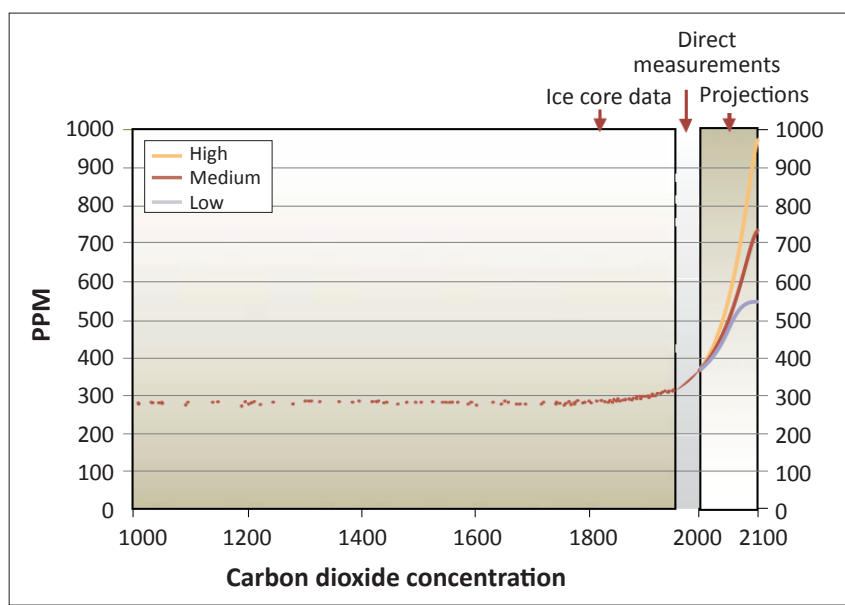

Source: Intergovernmental Panel on Climate Change, 2001, 'Climate Change 2001: The scientific basis', Contribution of Working Group I to the Third assessment report of the Intergovernmental Panel on Climate Change, Cambridge, Cambridge University Press

FIGURE 3: Historical trend and projections of the carbon dioxide concentration in Earth's atmosphere (1000 CE - $2100 \mathrm{CE})$.

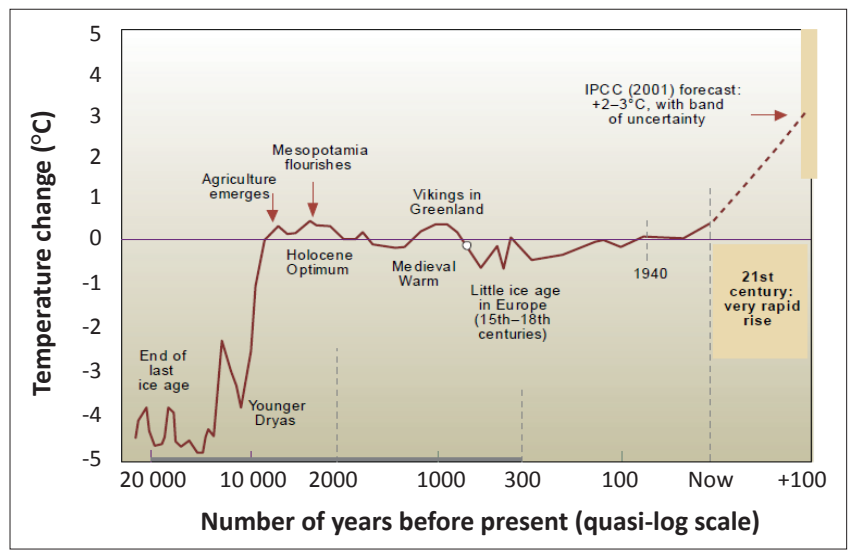

Source: Intergovernmental Panel on Climate Change, 2001, 'Climate Change 2001: The scientific basis', Contribution of Working Group I to the Third assessment report of the Intergovernmental Panel on Climate Change, Cambridge, Cambridge University Press

FIGURE 4: Earth's surface temperature variation curve over the past 20000 years. 
(daily maximum temperatures) from 1991-2008 to determine the isotherm dynamics. Keeping $30^{\circ} \mathrm{C}$ as the reference isoline, it was observed that by the end of 1990s, there was an upward shift of about $300 \mathrm{~m}$ in the reference isoline from its 1991-1995 position in the $\mathrm{HKH}$ region (Figure 5). According to the Pakistan Meteorological Department (Shahid 2013), the northern parts of the country have experienced an increase in temperature ranging from $0.8^{\circ} \mathrm{C}$ to $1.5^{\circ} \mathrm{C}$ between 1990 and 2010

\section{The impact of glacial lake outburst floods on mountain communities in Pakistan}

As a result of the rugged topography and political constraints, the Himalayan belt has long been isolated from scientific investigation. Lack of sufficient data makes it difficult to understand and identify the potential risks from natural hazards to the communities residing in the area. Researchers working on the domain of GLOFs, however, are making use of satellite imagery to monitor the response of glaciers to rising temperatures and have identified the expansion of existing lakes and the initiation of new ones. Several glacial lakes have been marked as potential risk of outburst floods in the region.

The entire belt has experienced an increased number of such devastating hazards as GLOFS; for instance Nepal has experienced about 24 GLOF events in the past two decades (1990s and 2000s). About 23\% of the Karakoram Range is under widespread glacial cover. The range accommodates about 2398 glaciers supplied by the Shyok River basin (about 37\%) followed by the Hunza River basin (34\%) and Shigar River basin (24\%). Siachen, Hispar, Biafo, Baltoro and Batura are some of the largest glaciers present in this range. As a result of the political instability in the region, these areas are difficult to access and so detailed mapping of the glaciers in Pakistan has yet to be undertaken for future reference and research. As such, Figure 6 provides a general view of the glacial stretch in the Karakoram basins, whilst Table 1 provides a summary of the major glacial lakes in the different river basins of the Karakorum Range.

Hewitt (1982) reported that 35 destructive outburst floods have occurred in the Karakoram Range during the past 200 years (Figure 7), including the growth and disappearance of Virjerab Lake in the Hunza region as a result of glacial shift. There was also a series of GLOF events in the upper Hunza valley within short intervals during 2008, which had devastating impacts on the communities living in these high risk areas. The glacial lakes of the Karakoram Range vary in type based on their location in the glacial system (Table 2). These lakes can be further categorised into various risk profiles on detailed study. Satellite data analysis has shown the presence of about 887 lakes in the Karakorum Range, out of which 492 are major lakes and 16 are plotted as probable future GLOF sites (Ashraf et al. 2011).
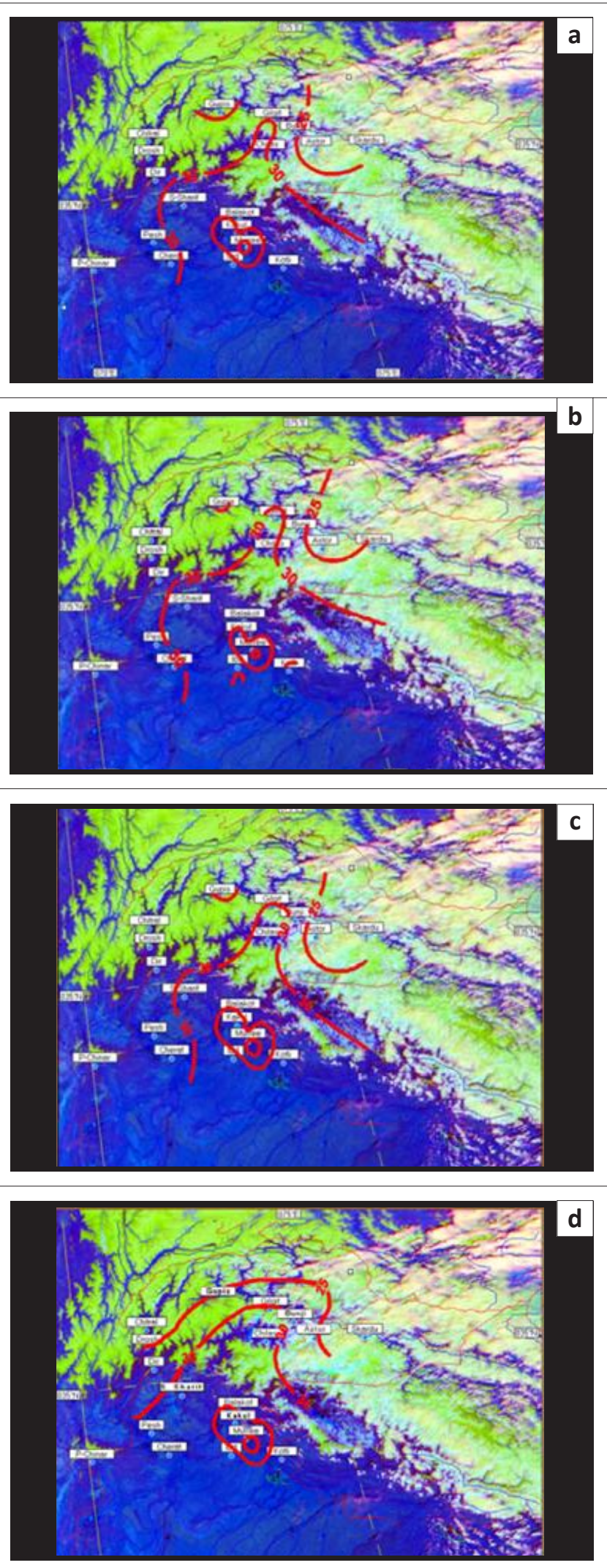

Source: Rasul, G., Dahe, Q. \& Chaudhry, Q.Z., 2008, 'Global warming and melting glaciers along southern slopes of HKH ranges', Pakistan Journal of Meteorology 5(9), 63-76, viewed 10 November 2013, from http://www.pmd.gov.pk/rnd/rnd_files/ vol5 issue9.htm

FIGURE 5: Shifting isothermic dynamics along the southern slopes of the Hindu Kush-Karakoram-Himalayas ranges showing a general northward trend. Isotherms based on mean summer maximum temperature: April-June for (a) 1991-1995, (b) 1995-2000, (c) 2001-2005 and (d) 2006-2008. 
Recently, research has been carried out within the Pakistan GLOF project under the ambit of the Pakistan Meteorological Department in the Himalayan districts of the country, to assess the probability of GLOF events and undertake risk profiling of the vulnerable communities in the vicinity of the glaciers. One of the findings of this study highlighted the Chitral district as a potential hazard site for GLOFs. It is the largest district of the Khyber Pakhtunkhwa Province

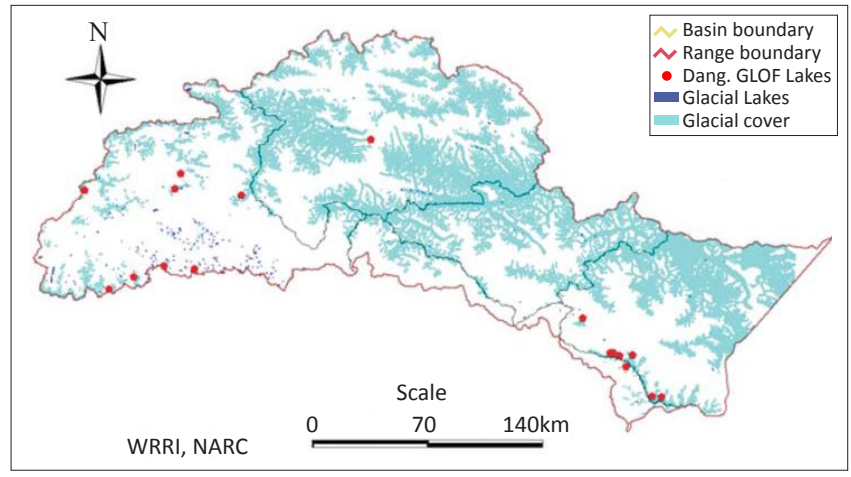

Source: Ashraf, A., Roohi, R., Naz, R. \& Mustafa, N., 2011, 'Identification of glacial flood hazards in Karakoram Range using remote sensing technique and risk analysis', Scientific Journal of COMSATS - Science Vision 16 \& 17, viewed 05 November 2013, from http://www. sciencevision.org.pk/Backlssues/Vol16_Vol17/11_Vol16_and_17_Identification_of_Glacial Flood_Hazards_ArshadAshraf.pdf

Dang, potentially dangerous, GLOF, glacier lake outburst flood.

FIGURE 6: Glacial environment and lakes with a potential glacial lake outburst flood threat in different Karakoram river basins, Pakistan. of Pakistan, located at the foothills of the Hindu Kush Range. Chitral has been experiencing outburst flood events throughout its history and the most devastating of these is said to have initiated from Chiantar Glacier in Broghil valley about 350 years ago. Chitral hosts about 542 glaciers, out of which 187 glaciers have developed glacial lakes. About 20 potential sites for outburst floods have been marked in the valleys of Golain, Laspoor, Yarkhoon, Terich and Reshun in Chitral. The increase in frequency of outburst floods in the region can be indicated by the fact that, within a short time span of 12 years, the district has witnessed more than eight GLOF events. Some of the major events include the outburst floods of Yarkhon Lasht (2003), Brep (2005), Sonoghor valley (2007), Bindo Gol (2010) and Buni (2011). According

TABLE 1: Overview of the glacial lakes in the major river basins of the Karakoram Range, Pakistan.

\begin{tabular}{lllll}
\hline Basins & $\begin{array}{l}\text { Total } \\
\text { lakes }\end{array}$ & $\begin{array}{l}\text { Lakes } \\
\text { areas }\left(\mathbf{k m}^{2}\right)\end{array}$ & $\begin{array}{l}\text { Major } \\
\text { lakes }\end{array}$ & $\begin{array}{l}\text { Potential } \\
\text { GLOF lakes }\end{array}$ \\
\hline Gilgit & 614 & 39.2 & 380 & 8 \\
Hunza & 110 & 3.2 & 47 & 1 \\
Shigar & 54 & 1.1 & 11 & - \\
Shyok & 66 & 2.7 & 31 & 6 \\
Indus region & 43 & 1.6 & 23 & 1 \\
\hline Total & $\mathbf{8 8 7}$ & $\mathbf{4 7 . 7}$ & $\mathbf{4 2 9}$ & $\mathbf{1 6}$ \\
\hline
\end{tabular}

Source: Rasul, G., Dahe, Q. \& Chaudhry, Q.Z., 2008, 'Global warming and melting glaciers along southern slopes of HKH ranges', Pakistan Journal of Meteorology 5(9), 63-76, viewed 10 November 2013, from http://www.pmd.gov.pk/rnd/rnd_files/vol5_issue9.htm GLOF, glacier lake outburst flood.

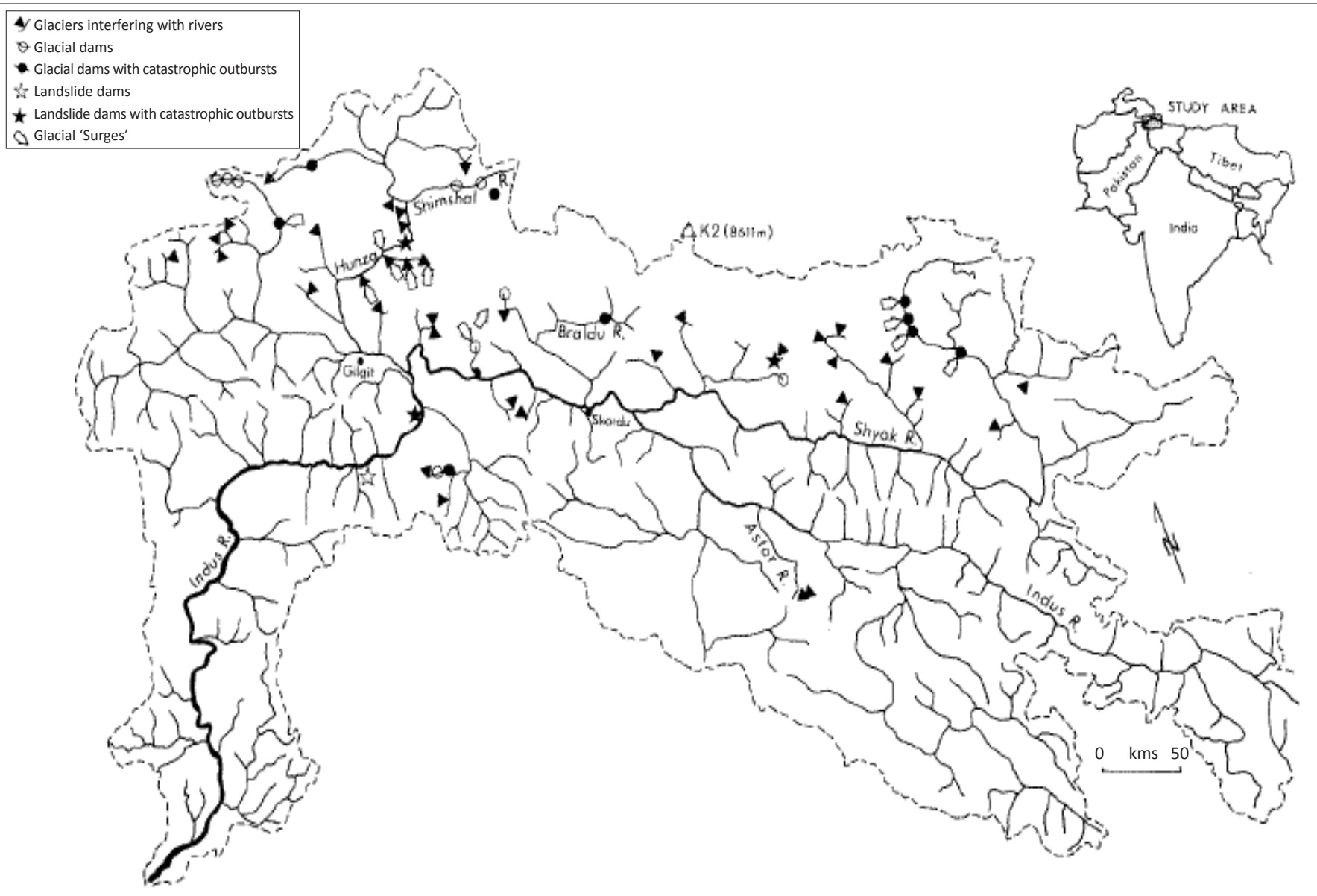

Source: Hewitt, K., 1982, 'Natural dams and outburst floods of the Karakoram Himalaya', in J.W. Glen (ed.), Hydrological aspects of alpine and high mountain areas - International Association of Hydrological Sciences Publication 138, Proceedings of the 2nd Exeter Symposium, Exeter, 19-30 July, pp. 259-270

FIGURE 7: Distribution of glacial lakes and related glacial events in the upper Indus River basin. 
TABLE 2: Summary of the different types of glacial lakes in the Karakoram Range, Pakistan.

\begin{tabular}{|c|c|c|c|c|c|c|}
\hline \multirow[t]{2}{*}{ Glacier type } & \multicolumn{6}{|c|}{ River basins } \\
\hline & Gilgit & Hunza & Shigar & Shyok & Indus & Total \\
\hline Cirque & 53 & - & - & 2 & - & 55 \\
\hline End moraine dammed & 100 & 4 & - & 12 & 12 & 128 \\
\hline Lateral moraine dammed & 49 & 3 & 1 & 3 & 6 & 62 \\
\hline Erosion & 283 & 20 & - & 26 & 13 & 342 \\
\hline Subglacial & 2 & 55 & 30 & 11 & 4 & 102 \\
\hline Valley & 125 & 24 & 2 & 8 & 6 & 165 \\
\hline Blocked & 2 & 4 & 21 & 4 & 2 & 33 \\
\hline Total & 614 & 110 & 54 & 66 & 43 & 887 \\
\hline
\end{tabular}

Source: Hewitt, K., 1982, 'Natural dams and outburst floods of the Karakoram Himalaya', in J.W. Glen (ed.), Hydrological aspects of alpine and high mountain areas - International Association of Hydrological Sciences Publication 138, Proceedings of the 2nd Exeter Symposium, Exeter, 19-30 July, pp. 259-270

to Pakistan Meteorological Department (PMD) (n.d.), the outburst flood event generated by the Buni Glacier caused severe damage to houses in its path. The latest addition to the list of these devastating events occurred on 31 July 2013 in Reshun valley, with its source from the Reshun Glacier. It resulted in devastating impacts on the community in a matter of seconds: about 40 houses, 30 animal corrals, 20 shops and cultivated land including crops and orchards were wiped away.

Gulkin Glacier on the Karakorum Highway experiences an average of two to three GLOF events every year. Gulkin Glacier feeds the newly formed Attabad Lake in Hunza, which is another potential threat for the downstream population in case the landslide-generated lake breaches. Passu Glacier has also been undergoing a rapid retreat of about $20 \mathrm{~m}$ over the past 15 years and a similar phenomenon is being observed at Baltoro Glacier, which is confirmed by the disappearance of most of the low-lying tributaries and the depletion of Liligo and Silili Glaciers.

As a result of the increasing intensity and frequency of GLOFs, certain positive steps have been taken by the Pakistan Government and concerned departments to closely monitor the variation in the glacial environment and to devise methods for community preparedness if such an event triggers in the future. For glacier monitoring in the $\mathrm{HKH}$ region, the Pakistan Meteorological Department has installed about 14 automatic weather stations at different elevation points. With the installation of these gauging stations, the ground data obtained can help in assessing the real-time situation of the country's glacial terrain and timely strategies can be devised for minimising the increasing risk of GLOFs in Pakistan.

\section{Recommendations}

To facilitate the greatest risk reduction, there should be a systematic approach for monitoring the varying glacial responses along the entire stretch of the Himalayas. Mutual cooperation and data sharing amongst the nations in this belt can help in effective assessment of the probable risk of GLOFs. Satellite imagery should be combined with the data obtained from various weather stations to develop a more realistic output of outburst floods in the region. Community awareness and training programmes must be organised to make people familiar with the increasing risks and enhance their coping capacity. Finally, focus must be laid on developing an effective early warning system for GLOFs to lessen the loss of life, livelihood, infrastructure and damage to environment in the region.

\section{Conclusion}

Earth's climate is undergoing a rapid change resulting from increasing impacts of natural and anthropogenic activities during the past few decades. As a result of the shifting trend of warming temperatures, glaciers are experiencing a much faster rate of depletion and retreat. This scenario has generated many new glacial lakes and caused the growth of the existing ones in the glacial terrains throughout the globe. These glacial lakes are one of the major threats to mountain communities as they are unstable and frequently burst, resulting in outburst floods. The Himalayan region, the largest snow covered area outside the polar regions, is vulnerable to the increasing risk of GLOFs, and has experienced some of the most devastating outburst events in the recent past. It is therefore the foremost need of the Himalayan nations to develop strategies and mechanisms for close monitoring of the glaciated terrain and cooperate in reducing the frequent devastating impacts of GLOFs on the communities vulnerable to this natural hazard.

\section{Acknowledgements Competing interests}

The authors declare that they have no financial or personal relationships that may have inappropriately influenced them in writing this article.

\section{Authors' contributions}

S.R. (National University of Science and Technology) was the main contributor. A.A. (National University of Science and Technology) made conceptual contributions to the article, whilst M.N.B. (National University of Science and Technology) provided technical expertise and critical overview of the article.

\section{References}

Ashraf, A., Roohi, R., Naz, R. \& Mustafa, N., 2011, 'Identification of glacial flood hazards in Karakoram Range using remote sensing technique and risk analysis', Scientific Journal of COMSATS - Science Vision 16 \& 17, viewed 05 November 2013, from http://www.sciencevision.org.pk/Backlssues/Vol16_Vol17/11_Vol16_and_17_ Identification_of_Glacial_Flood_Hazards_ArshadAshraf.pdf 
Bajracharya, S.R., Mool, P.K. \& Shrestha, B.R., 2007, 'Impact of climate change on Himalayan glaciers and glacial lakes: Case studies on GLOF and associated hazards in Nepal and Bhutan', Report by the International Centre for Integrated Mountain in Nepal and Bhutan', Report by the International Centre for Integrated Mountain Regional Office Asia and the Pacific, Kathmandu.

Bashir, F. \& Rasul, G., 2010, 'Estimation of average snow cover over northern Pakistan' Pakistan Journal of Meteorology 7(13), viewed 10 November 2013, from http:// www.pmd.gov.pk/rnd/rnd files/vol7 issue13.htm

Dyhrenfurth, G.O., 1955, To the Third Pole: The history of the High Himalaya, Werne Laurie, London.

Goudie, A., 1981, The human impacts: Man's role in environmental change, Blackwell Publishing Ltd, Malden.

Hewitt, K., 1982, 'Natural dams and outburst floods of the Karakoram Himalaya', in J.W. Glen (ed.), Hydrological aspects of alpine and high mountain areas International Association of Hydrological Sciences Publication 138, Proceedings of the 2nd Exeter Symposium, Exeter, 19-30 July, pp. 259-270.

Intergovernmental Panel on Climate Change, 2001, 'Climate Change 2001: The scientific basis', Contribution of Working Group I to the Third assessment report of the Intergovernmental Panel on Climate Change, Cambridge, Cambridge University Press.

International Centre for Integrated Mountain Development, 2001, Glacial lakes and glacial lake outburst floods in Nepal, viewed 29 October 2013, from http://www. icimod.org/dvds/201104_GLOF/reports/final_report.pdf

Ives, J.D., Shrestha, R.B. \& Mool, P.K., 2010, Formation of glacial lakes in the Hindu Kush-Himalayas and GLOF risk assessment report, International Centre fo Integrated Mountain Development, Kathmandu, viewed 29 October 2013, from http://www.unisdr.org/files/14048_ICIMODGLOF.pdf

Lal, M., 2002, 'Possible impacts of global climate change on water availability in India', Report to Global Environment and Energy in the 21st Century, Indian Institute of Technology, New Delhi.
Milankovitch, M., 1920, Theorie Mathematique des Phenomenes Thermiques produits par la Radiation Solaire [Mathematical theory of thermal phenomena caused by solar radiation], Gauthier-Villars, Paris.

Miller, K.J. (ed.), 1984, The international Karakoram project, Cambridge University Press, Cambridge.

Pakistan Meteorological Department, n.d., Pakistan GLOF project, District Chitral, Pakistan, United Nations Developemnt Programme, Islambad, viewed 02 November 2013, from https://adaptation-fund.org/system/files/AFB. PPRC.3.14\%20Part\%202.pdf

Rasul, G., Dahe, Q. \& Chaudhry, Q.Z., 2008, 'Global warming and melting glaciers along southern slopes of HKH ranges', Pakistan Journal of Meteorology 5(9), 63-76, viewed 10 November 2013, from http://www.pmd.gov.pk/rnd/rnd files/ vol5 issue9.htm

Richardson, S.D. \& Reynolds, J.M., 2000, 'An overview of glacial hazards in the Himalayas', Quaternary International 65/66, 31-47. http://dx.doi.org/10.1016/ S1040-6182(99)00035-X

Shahid, J., 2013, 'Glacial lakes threat to villages, says expert', Dawn.com, 25 February, viewed 13 November 2013, from http://www.dawn.com/news/788579/glaciallakes-a-threat-to-villages-says-expert

United Nations Development Programme, 2010, Glacial lake outburst flood (GLOF) risk reduction in the Himalayas: Project facts - Himalayas, March 2008 February 2009, viewed 01 November 2013, from http://cq-publish.dev.undp.org/ content/dam/undp/library/crisis\%20prevention/disaster/asia_pacific/Regional Glacial\%20Lake\%20Outburst\%20Flood\%20(GLOF)\%20Risk\%20Reduction\% 20 Himalayas.pdf

Walder, J.S. \& Costa, J.E., 1996, 'Outburst floods from glacier-dammed lakes: The effect of mode of lake drainage on flood magnitude', Earth Surface Processes and Landforms 21,701-723. http://dx.doi.org/10.1002/(SICI)10969837(199608)21:8<701::AID-ESP615>3.0.CO;2-2 